\author{
Single Stranded Conformation Polymorphism 분석에 의한 돼지 \\ Duroc 품종의 미토콘드리아 DNA 유전적 변이 \\ 조인철* · 정용환* · 정진관* . 성필남* . 김병우** . 이정규** · 전진태** \\ 농촌진흥청 제주농업시험장*, 경상대학교 응용생명과학부**
}

\title{
Genetic Variation of Mitochondrial DNA in Duroc (Sus Scrofa) Using Single Stranded Conformation Polymorphism Analysis
}

I. C. Cho*, Y. H. Jung*, J. K. Jung*, P. N. Seong*, B. W. Kim**,

J. G. Lee** and J. T. Jeon**

National Jeju Agricultural Experiment Station, R.D.A.*

Division of Applied Life Science, Gyeongsang National University**

\begin{abstract}
The mitochondrial DNA(mtDNA) D-loop region was amplified from Duroc(Sus scrofa) by polymerase chain reaction(PCR). The oligonucleotide primer used to amplify the Sus scrofa mtDNA D-loop region was designed using tRNA-Pro and tRNA-Phe sequence in mtDNA regions highly conserved in many other animal species. There were 1,145 base pairs(bp) in the D-loop region. The middle of the region contained 10 tandem repeat of an 10-bp Sus scrofa-specific sequence, TACACGTGCG. We designed primers for PCR-mediated single stranded conformation polymorphism(SSCP) analysis that amplified a 345 bp fragment, which contained the most variable region according to our sequencing data. SSCP analysis of denatured amplification products was carried out by polyacrylamide(8\%) gel electrophoresis followed by ethidium bromide staining. The SSCP analysis identified two band patterns(A and B) and comparision of these two nucleotide sequences identified 21 base substitutions. These results show that SSCP analysis of the D-loop region is useful for detecting the genetic polymorphism.
\end{abstract}

(Key words : D-loop, SSCP, Sus scrofa, Tandem repeat)

\section{I 서 론}

돼지의 동물 분류학적 위치는 우제류목 (Artiodactyla) 멧돼지과(Suidae) 멧돼지속(Sus) 집 돼지종(S. scrofa domesticus)로 분류된다. Darwin (1868)은 돼지의 기원을 표현형적 차이에 의하 여 유럽종(S. scrofa)과 아시아종(S. indicus)으로 분류하였다. 유럽종은 유럽 야생종에서 진화한 것으로 추정하였으나, 아시아종의 진화에 대해 서는 알려져 있지 않다. 18세기에서 19세기초 유럽 돼지 품종을 개량하기 위하여 아시아 돼
지가 유럽에 전파되었으며(Jones 1998), 이중 중 국 돼지품종이 유럽에 전파되어 품종형성에 기 여한 것으로 보고되고 있다(Giuffra 등, 2000). 국내에서 사육되고 있는 돼지 품종으로는 랜드 레이스, 대요크셔, 듀록이 대부분 차지하고 있 고, 일부 햄프셔, 버크셔, 피에트레인 품종이 사육되고 있으며, 제주지역에서는 제주 재래돼 지가 부분적으로 사육되고 있다.

미토콘드리아 DNA는 핵 DNA에 비하여 염 기 치환율이 훨씬 빠르다. 그래서 최근에는 포 유류 동물들의 유전적 상관을 추정하기 위하여

Corresponding author : J. T. Jeon, (Division of Applied Life Science, Gyeongsang National University, Jinju 660701, Korea. Tel : 055-751-5516, E-mail : jtjeon@nongae.gsnu.ac.kr 
계통유전학적 연구에 널리 이용되고 있다. 미 토콘드리아 DNA는 환상구조(circular form)이며, control region인 D-loop, 2개의 $\operatorname{rRNA}(12 \mathrm{~S}, 16 \mathrm{~S})$ 그리고 13 개의 peptide coding gene으로 구성되 어 있으며, 이들 유전자 사이에 22개의 tRNA가 존재한다. 포유류의 우제류를 분류하는데는 주 로 mitochondrial DNA의 12S, $16 \mathrm{~S}$ rRNA (Myyamoto and Boyler, 1989; Miyamoto et al., 1990; Kraus and Miyamoto, 1991)와 $C O \Pi$ 와 Cytb(Honeycutt et al., 1995; Irwin et al., 1991) 유전자가 주로 이용되고 있다. 최근 반추동물 인 소에 대한 연구는 계통유전학적으로 분석한 결과 비반추동물인 돼지 보다는 고래와 더 가 까운 혈연관계에 있는 것으로 보고되고 있다 (Arnason et al., 1991; Ursing and Arnason, 1998).

Single stranded conformation polymorphism (SSCP) 분석은 PCR 산물을 formamide 등의 변 성체를 첨가하여 single-strand DNA로 변성시켜 비변성 polyacrylamide 겔에서 전기영동하는 방 법으로서 염기서열에 하나의 염기치환 또는 짧 은 염기서열의 결실, 삽입 등 구조이상이 존재 하면 single-strand DNA의 이동도가 변화하여 서로다른 밴드 유형을 나타내는 성질을 이용하 는 기법으로서 종간 및 종내에서 유전적 변이 관찰에 자주 이용되고 있는 실정이다(Oh and Jung, 2001).

따라서 본 실험은 국내에서 사육되고 있는 돼지 Duroc 품종의 mtDNA D-loop에서의 유전 적 다양성을 조사하여 유전적 종보존을 위한 기초자료를 제공하고자 유전적 변이 관찰에 용 이한 SSCP 기법을 이용하여 실시하였다.

\section{재료 및 방법}

\section{1. 공시동물 및 혈액채취}

실험에 공시된 돼지는 제주농업시험장에서 사육하고 있는 혈통등록이 되어 있는 듀록 80 두를 비보정법으로 $18 \mathrm{G}$ gauge needle이 부착된 주사기로 경정맥으로부터 혈액을 채혈하였으 며, DNA 추출 전까지 $4^{\circ} \mathrm{C}$ 뱅장고에서 보관하 였다.

\section{DNA 추출 및 정제}

혈액으로부터 genomic DNA의 추출은 Wizard Genomic DNA Purification Kit(Promega, USA)를 이용, 전기영동에 의하여 $\mathrm{DNA}$ 농도를 정량한 후 $4^{\circ} \mathrm{C}$ 뱅장고에 보관하였다.

\section{3. 돼지 Duroc 품종의 전체 D-loop 증폭}

돼지 Duroc 품종의 mtDNA D-loop의 전체 염기 서열 분석을 위하여 기존에 보고된 돼지 $\mathrm{mtDNA}$ 서열(Genbank accession number : NC_000845, AF034253)을 가지고 tRNA-Pro 및 tRNA-Phe sequence 일부지역을 primer를 제작하였으며, primer sequence는 아래와 같다.

D-loop F : 5'-TCT-AAC-TAA-ATT-ATT-CCC-TG-3'

D-loop R : 5'-ATA-ATT-TAA-GCT-ACA-TTA-AC-3'

PCR 반응은 $10 \times$ buffer $2.5 \mu \ell \quad \mu \ell$ 10 pmol primer 각 $1.5 \mu \ell$ Taq $0.3 \mu \ell$ DW 15.2 $\mu \ell \quad \mu \ell \quad \mu \ell$ 를 반응하였으며, PCR 반응조건은 $94^{\circ} \mathrm{C}$ 서 10 분간 pre-denaturation을 실시하고 $94^{\circ} \mathrm{C}$ 서 1 분, $55^{\circ} \mathrm{C}$ 서 1 분, $72^{\circ} \mathrm{C}$ 서 1 분 총 30 cycle을 수 행한 후 $72^{\circ} \mathrm{C}$ 서 10 분간 extension을 실시 후 $4^{\circ} \mathrm{C}$ 서 종료하였다.

\section{SSCP 분석}

SSCP 분석을 위하여 D-loop 전체 염기서열을 분석하여 가장 변이가 심한 부위를 SSCP F (5'-CGT ACA CGC GCA TAT AAG CAG-3')와 SSCP R (5'-CTA TAT TCA GAT TGT GGG CG-3')의 primer를 제작하였다. PCR 증폭 후 SSCP 반응조건은 $2.5 \mu \ell$ | PCR product와 7.5 $\mu \ell$ | denaturing buffer(95\% formamide, 0.05\% xylene cyanol 및 $0.05 \%$ bromophenol blue)를 혼 합하여 $95^{\circ} \mathrm{C}$ 서 3 분간 끊인 후, ice 위에서 2 분 간 침지한 후 $8 \%$ polyacrylamide gel(acrylamide : bis-acrylamide $=49: 1$ )에서 $200 \mathrm{~V}$ 전압하에서 16 시간 $0.5 \times \mathrm{TBE}$ buffer에서 전기영동 하였다. 그 후 gel은 $0.5 \mathrm{\mu g} / \mathrm{m} \ell$ 의 ethidium bromide(EtBr) 
로 10 분간 염색한 후 UV image analyzer로 관 찰하였다.

\section{5. 유전자 cloning 및 Sequencing}

PCR product는 TOPO TA cloning kit (Invitrogen, USA)를 이용하여 ligation을 실시하였 다. cloning된 DNA fragment는 Cy5-labeled vector inner primer인 M13-40 primer(5'-CGC CAG GGT TTT CCC AGT CAC GAC-3')와 M13-reverse primer(5'-TTT CAC ACA GGA AAC AGC TAT GAC-3')를 이용하였으며, 각 샘플은 $\mathrm{Cy}_{5}{ }^{\mathrm{TM}}$ AutoCycle ${ }^{\mathrm{TM}}$ Sequencing Kit를 이용하여 Plasmid DNA와 반응시켜 Sequencing PCR을 수행하였다. 그 후 gel buffer로서 0.6\% TBE buffer를 이용하였고, ALFexpress DNA sequencer(Phamacia Biotech, USA)를 $1500 \mathrm{~V}$ 에서 700 분간 6\% acrylamide-7M urea gel에서 전기영동하였다. Sequence data는 Clustal W를 이용하여 염기서열의 정렬을 수 행하였다.

\section{III 결과 및 고찰}

돼지 Duroc 품종의 D-loop 전체 유전자 염기 서열 분석을 위하여 기존에 보고된 GenBank (accession number: NC_000845, AF034253)와 EMBL(accession number : AJ002189) database를 이용 하여 primer 제작은 tRNA-Pro 지역 일부 를 Forward로 하고 tRNA-Phe 지역 일부를 Reverse로하여 D-loop 전체를 PCR 증폭 후 cloning 및 Sequencing을 하였다. 그 결과 돼지 Duroc 품종의 전체 D-loop은 1,145 base pairs 였으며, Sus scrofa- specific sequence인 tandem repeat(TACACGTGCG)가 10개 반복되는 특징이 있었다. 이 결과는 $\operatorname{Lin}$ 등 (1999)이 보고한 돼 지(Landrace) D-loop 전체 염기수는 $1,175 \mathrm{bp}$ 였으 며, 이중 tandem repeat가 13 개 존재하는 것을 고려하면 tandem repeat를 제외한 나머지 부분 에서 돼지 D-loop 전체 염기수는 일치하는 결 과를 보였으나, Ursing 등 (1997)은 D-loop 전체 염기수는 $1,246 \mathrm{bp}$ 를 보고하였으며, 이중 tandem repeat가 20개 존재하는것을 고려하여도 1 base pair가 불일치하는 결과를 보였다.

이들 sequencing data를 Clustal W 프로그램을 이용하여 alignment를 수행하였으며, 가장 변이 가 심한 tandem repeat (TACACGTGCG) 후반부 지역을 이용하여 SSCP용 primer를 제작하였다.

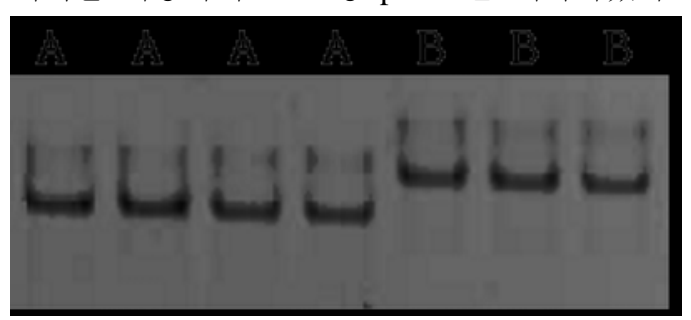

Fig. 1. SSCP band patterns of the mt D-loop region in Duroc(Sus scrofa). The PCRamplified DNA fragment were denatured by heating and then loading on to a $8 \%$ polyacrylamide gel. The result were detected by $\mathrm{EtBr}$ staining. $\mathrm{A}$ and $B$ indicate the SSCP types.

SSCP 분석결과 2가지 패턴(A와 B type)으로 나누어 졌으며(Fig. 1), 이들에 대한 유전자 염 기서열 분석을 위하여 sequencing 결과는 Fig. 2 와 같다. A 유형은 $333 \mathrm{bp}$ 인 반면 $\mathrm{B}$ 유형은 $12 \mathrm{bp}$ 가 많은 $345 \mathrm{bp}$ 로 나타났다(Fig. 2와 Table 2). 얻어진 $\mathrm{A}$ 와 $\mathrm{B}$ 유형의 염기서열 결과들은 각각 GenBank(AY243482, AY338472)에 등록을 하였다.

Fig. 2의 SSCP 분석 결과 두 가지 유형(A와 B type)을 보였으며, 이들의 염기서열을 분석한 결과 21개 부위에서 유전자 첨가/결실(insert/ deletion) 및 치환(substitution)이 되었으며, 가장 큰 특징은 TAAAACACTTA의 11 개 염기가 한 번 더 중복(duplication)되는 특징이 있었다. 미 토콘드리아 DNA는 모계유전 특징이 있기 때문 에 이러한 결과를 추정하면 Duroc 품종 형성과 정에 품종간 교잡(유전자 교차)에 의해 나타난 결과로 사료된다.

Table 1은 돼지 Duroc 품종의 A, B type의 분 포를 나타낸 것으로서 전체 80 두 중 71 두가 $\mathrm{A}$ 유형(88.75\%)이었고 나머지 9두가 B 유형 (11.25\%)이었다. 
20

40

60

80

A GTACACGCGCATATAAGCAGGTAAATTATTAGCTCATCAAACCCCCCTTACCCCOCATTAAACTTATGCTCTACACACC

B $\mathrm{CSB}-2$

$100 \quad 120 \quad 140 \quad 160$

A CTATAACGCCTTGCCAAACCCCAAAAACAAAGCAGAGTGTACAAATACAATAAGCCTAACTTACACTAAACAACATTTAA

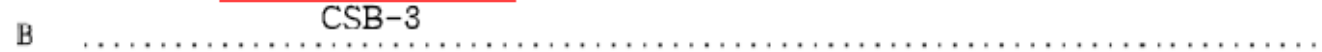

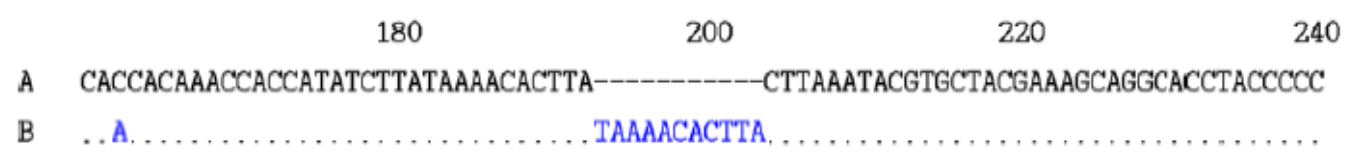

$260 \quad 300 \quad 320$

A C-TAGATTTTTACGC-AATCTACCATAAATAAATTTAAAATTACAACACAATAACCTCCCAAAATATA-GCACCTATTTC

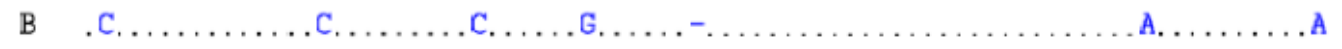

$340 \quad 346$

A GgTATACGCCCACAATCTGAataTAg

B A, C..................

Fig. 2. Nucleotide alignment of the D-loop region in Duroc mtDNA. Nucleotide sequences were displayed from $5^{\prime}$ to $3^{\prime}$. Dots indicate that the base is identical to that of A. A, wild type; $B$, variant type.

GenBank accession number (A, AY243482; B, AY338472)

Table 1. Number of Detected SSCP Variants

\begin{tabular}{ccc}
\hline \multirow{2}{*}{ Type* $^{*}$} & \multicolumn{2}{c}{ Duroc } \\
\cline { 2 - 3 } & No** $^{* *}$ & Frequency(\%) \\
\hline \hline A & 71 & 88.75 \\
B & 9 & 11.25 \\
\hline
\end{tabular}

* SSCP Type were given in Fig. 1.

$* *$ No $=$ number of individual.

Table 2. Characteristics of mtDNA D-loop Region(partial) from the SSCP Variants.

\begin{tabular}{|c|c|c|c|c|c|}
\hline \multirow{2}{*}{ Туре* } & \multirow{2}{*}{$\begin{array}{c}\text { Length } \\
\text { (bp) }\end{array}$} & \multicolumn{4}{|c|}{ Base Content(\%) } \\
\hline & & A & $\mathrm{C}$ & G & $\mathrm{T}$ \\
\hline A & 333 & $\begin{array}{c}130 \\
(39.0) \\
\end{array}$ & $\begin{array}{c}97 \\
(29.1) \\
\end{array}$ & $\begin{array}{c}29 \\
(8.7) \\
\end{array}$ & $\begin{array}{c}77 \\
(23.1) \\
\end{array}$ \\
\hline B & 345 & $\begin{array}{c}138 \\
(40.0)\end{array}$ & $\begin{array}{c}100 \\
(28.9)\end{array}$ & $\begin{array}{c}29 \\
(8.4)\end{array}$ & $\begin{array}{c}78 \\
(22.6)\end{array}$ \\
\hline
\end{tabular}

$\mathrm{A}$ and $\mathrm{B}$ types were given in Fig. 1.
미토콘드리아 DNA의 특징은 아데닌/티민(A/T) 함량이 구아닌/시토신 $(\mathrm{G} / \mathrm{C})$ 함량 보다 많은 특 징이 있다. Table 2에서는 Fig 2의 염기서열 분 석결과를 염기종류별 비율을 나타낸 것으로서 $\mathrm{A}$ 와 $\mathrm{B}$ 유형에 따른 염기분포 비율은 비슷하였 으며, 아데닌/티민(A/T) 함량이 약 $62 \%$ 정도 분 포하고 있었다. Oh and Jung(2001)은 말에서 아 데닌/티민(A/T) 함량을 $64 \%$ 를 보고하였으며, 말 과 비슷한 분포 경향을 보였다.

결론적으로, 돼지 Duroc 품종의 mtDNA Dloop 부위를 SSCP 방법을 이용하여 분석한 결 과 뚜렷한 변이형이 관찰되었다. 이러한 연구 결과와 더불어 멧돼지속에 대한 더 많은 품종 을 확보하여 보다 더 빠르게 진화하는 특정 유 전자를 대상으로 추가 실험을 실시한다면, 품 종간 진화와 각 품종들의 유전자 이입 문제로 인한 다양성에 대한 실체를 명확히 구명할 수 있을 것으로 사료된다. 


\section{IV 요 약}

돼지 Duroc 품종의 mitochondria DNA D-loop 전체 유전자를 증폭하기 위하여 많은 동물에서 고도로 상동성이 높은 tRNA-Pro와 tRNA-Phe 염기서열 일부를 이용하여 oligonucleotide primer 를 제작하였다. 그 결과 Duroc 품종의 D-loop 전체 유전자는 1,145 base pairs 였으며, 그 중 간위치에 $10 \mathrm{bp}$ 의 Sus Scrofa-specific sequence (TACACGTGCG)가 10 개 존재하고 있었다. 돌 연변이 검출을 위하여 가장 변이가 심한 지역 을 primer 제작하여 $345 \mathrm{bp}$ 의 DNA 단편을 증 폭하였으며, Single Stranded Conformation Polymorphism(SSCP) 분석은 $8 \%$ polyacrylamide gel에 서 $200 \mathrm{~V}, 16$ 시간 전기영동하여 ethidium bromide $(\mathrm{EtBr})$ 로 10 분간 염색하여 UV image analyzer로 관찰하였다. 그 결과 두 개의 서로 다른 밴드 유형을 관찰하였으며, 21 개 부위에서 염기서열 변이가 관찰되었다. 이러한 결과는 유전적 다 양성 변이를 검출하는데 SSCP 분석이 유용한 도구라고 사료된다.

\section{$\mathrm{V}$ 인 용 문 헌}

1. Arnason, U., Gullberg, A. and Widegren, B. 1991. The complete nucleotide sequence of the mitochondrial DNA of the fin whale, Balae noptera physalus. J. Mol. Evol. 33:556-568.

2. Bjorn, M., Ursing, B. M. and Arnason, U. 1998. The Complete Mitochondrial DNA Sequence of the Pig(Sus scrofa). J. Mol. Evol. 47:302-306.

3. Bowling, A. T., Valle, A. D. and Bowling, M. 2000. A pedigree-based study of mitochondrial D-loop DNA sequence variation among arabian horses. Animal genetics 31:1-7.

4. Giuffra, E., Kijas, J. M. H., Amarger, V., Carlborg, A., Jeon, J.-T. and Andersson, L. 2000. The Origin of the Domestic Pig: Independent Domestication and Subsequent Introgression. Genetics 154:1785-1791.

5. Honeycutt, R. L., Nedbal, M. A., Adkins, R. M. and Janecek, L. L. 1995. Mammalian mitochondrial DNA evolution: a comparison of the cytochrome b and cytochrome c oxidase II genes. J. Mol. Evol. 40:260-272.
6. Irwin, D. M., Kocher, T. D. and Wilson, A. C. 1991. Evolution of the cytochrome $b$ gene of mammals. J. Mol. Evol. 32:128-144.

7. Jones, G. F. 1998. Genetic aspects of domestication, common breeds and their origin, pp. 17-50 in The Genetics of the Pig, edited by A. Ruvinsky and M. F. Rothschild. CAB International, Oxon, UK.

8. Kim, K. I., Yang, Y. H., Lee, S. S., Park, C., Ma, R., Bouzat, J. L. and Lewin, H. A. 1999. Phylogenetic relationships of Cheju horse to other horse breeds as determined by mtDNA D-loop sequence polymorphism. Animal Genetics 30:102-108.

9. Kraus, F. and Miyamoto, M. M. 1991. Rapid cladogenesis among the pecoran ruminants: evidence from mitochondrial DNA sequences. Syst. Zool. 40: 117-130.

10. Lin, C. S., Sun, Y. L. and Liu, C. Y. 1999. Complete nucleotide sequence of pig(Sus scrofa) mitochondrial genome and dating evolutionary divergence within Artiodactyla. Gene 236:107-114.

11. Miyamoto, M. M. and Boyler, S. M. 1989. The potential importance of mitomitochondrial DNA sequence data to eutherian mammal phylogeny. In: Fernholm, B., Bremer, B., Jornvall, H. (Eds.), The Hierarchy of Life. Elsevier, Amsterdam, pp. 437-450.

12. Miyamoto, M. M., Kraus, F. and Ryder, O. A. 1990. Phylogeny and evolution of antlered deer determined from mitochondrial DNA mitosequences. Proc. Natl. Acad. Sci. USA 87:6127-6131.

13. Miyamoto, M. M., Kraus, F., Laipis, P. J., Tanhauser, S. M. and Webb, S. D. 1993. Mitochondrial DNA phylogenies within Artiodactyla. In: Slalay, F.S., Novacek, M.J., McKenna, M.C. (Eds.), Mammal Phylogeny. Springer, New York, pp. 268-281.

14. Oh, M. Y. and Jung, Y. H. 2001. Mitochodrial DNA Polymorphism in Cheju and Tsushima Native Horse using SSCP analysis. Korean J. Genetics 23(1):35-43.

15. Orita, Iwahana, Kanazawa, Hayashi and Sekiya. 1989. Detection of polymorphisms of human DNA by the gel electrophoresis as single-strand conformation polymorphisms. Proc. Natl. Acad. Sci. USA. 86:2766-2770.

16. Ursing, B. M. and Arnason, U. 1998. The complete mitochondrial DNA sequence of the pig (Sus scrofa). J. Mol. Evol. 47:302-306.

17. Xu, X. and Arnason, U. 1994. The complete mitochondrial DNA sequence of the horse, Equus cabal- 
lus: extensive heteroplasmy of the control region. Gene 148:357-362.

18. Xu, X., Gullberg, A. and Arnason, U. 1996. The complete mitochondrial DNA (mtDNA) of the Donkey and mtDNA comparisions among four closely related mammalian species-pairs. J. Mol. Evol. 43: 438-446.

19. Xu, X., Janke, A. and Arnason, U. 1996. The complete mitochondrial DNA sequence of the Greater Indian Rhinoceros, Rhinoceros unicornis, and the phylogenetic relationship among Carnivora, Perissodactyla, and Artiodactyla (+Cetacea). Mol. Biol. Evol. 13(9):1167-1173.

20. Xu, X. and Arnason, U. 1997. The complete mitochondrial DNA sequence of the White Rhinoceros, Ceratotherium simum, and comparision with the mtDNA sequence of the indian Rhinoceros, Rhinoceros unicornis. Molecular Phylogenetics and Evolution. 7(2):189-194.

(접수일자 : 2003. 8. 12. / 채택일자 : 2003. 11. 15.) 